AFRREV, 10 (1), S/NO 40, JANUARY, $2016 \mid 61$

African Research Review

An International Multidisciplinary Journal, Ethiopia

Vol. 10(1), Serial No.40, January, 2016: 61-72

ISSN 1994-9057 (Print)

ISSN 2070--0083 (Online)

Doi: http://dx.doi.org/10.4314/afrrev.v10i1.6

\title{
Analysis towards Effective Policing in Nigeria
}

\section{Oyemwinmina, Christopher}

Security Department, University of Benin,

P.M.B. 1154, Benin City

Edo State, Nigeria

E-mail: Osaferis2@yahoo.com

GSM: +2347056022224

$\&$

\author{
Aibieyi, Stanley \\ Institute of Public Administration and Extension Services \\ University of Benin, Ekehuan Campus, \\ P.M.B 1154 \\ Benin City, Edo State, Nigeria \\ E-mail: Saibieyi@yahoo.com \\ GSM: +2348050283517
}

\begin{abstract}
Security of life and property is the bedrock of social, economic and political stability of any nation. Man as a unique creature with peculiar and complex nature could be instinctively unpredictable and uncontrollable. And this explains why humans are the major determinant and provider of security in a society. Governments of nations are therefore saddled with the responsibility of internal security through established agencies empowered by law. This duty is distilled into standard policing to enforce
\end{abstract}


law and order in the wake of a secured/safe environment. The standard of policing available to nation determines the level of development of that country. Unfortunately, the Nigeria police has not been able to live up to expectation in providing adequate security to the nation. In carrying out the research, the secondary source of information and data was utilized. The findings reveal that several factors are responsible for police inefficiency and ineffectiveness, which include corruption, poor funding by government and lack of confidence by the general public. The paper recommended some important strategies for effective policing which includes re-orientation of the police, proper training, provision of firearms, motivation and public responsibility.

\section{Introduction}

\section{Evolution of Nigeria Police Force}

The Pre-Colonial era in the West Coast of Africa witnessed a policing arrangement that was purely indigenous to the community of people involved. Emphasis was however on service, as traditional rulers used well able bodied men for the administration of justice. Although, no semblance of official organization characterized the policing arrangement on ground before the annexation of Lagos as a British Colony in 1861. The Colonialist however introduced warrant Chief through the Emirs in the North and Obas in the West to protect colonial trade and commerce. The economic constraint experienced by the British official between 1840 and 1861 then led to the emergence of the Lagos Consular Guard that comprise a 30 man guard to enforce law and order, and to maintain sanitary regulations.

In 1863, the 30 member Consular Guard was renamed Hausa Guard, So-named after ethnicity of the men recruited into the unit. It was further regularized in 1879 by an ordinance creating a constabulary for the Colony of Lagos. Thus, the Hausa Guard became known as Hausa Constabulary. On January 1, 1896, the Lagos Police Force was created and armed like the "Hausa Constabulary" While the South-South which includes the states of Akwa-Ibom, Bayelsa, Cross River, Delta, Edo and Rivers states were declared the oil River Protectorate in 1891 with Headquarters at Calabar where an armed Constabulary was formed. (Obaro 2014).

In 1900, the Royal Niger Constabulary was later divided into the Northern Nigerian Police and the Northern Nigeria Regiment. In the Southern Region, the Lagos Police Force and part of the Niger Coast Constabulary collapsed into the Southern Nigeria Regiments. Although Nigeria amalgamation of the Southern and Northern protectorate took place in 1914, it was not until 1930 that the Southern and Northern regional Police forces were brought together to form the Nigeria Police Force. Their Headquarters was to be in Lagos.

The new Police Forces were in addition to normal civil police duties, responsible for dealing with internal disturbance and external aggression. In 1960 
under the first Republic, these forces were first regionalized and then nationalized. In 1943 the Northern and Western Regions of Nigeria established their arm regional police. There existed a local government police. They were all merged into the Nigeria Police Force in 1968. The Nigerian Police Force graduated from Colonial policing machinery to a national security outfit (Olong and Agbonika 2013).

Successive Nigeria Constitutions since 1979 have provided for the existence of the Nigeria Police Force as the national police of Nigeria with exclusive jurisdiction throughout the country.

\section{Organisation}

The Nigerian Police Force maintains a three-tier administration structure of departments, zonal and state commands. Table below shows the administrative structure.

\begin{tabular}{|l|l|l|l|}
\hline S/N & TITLE & DEPARTMENT & RESPONSIBILITIES \\
\hline 1. & $\begin{array}{l}\text { Department of } \\
\text { Finance and } \\
\text { Administration }\end{array}$ & $\begin{array}{l}\text { Finance and } \\
\text { Administration }\end{array}$ & General Administration \\
\hline 2. & $\begin{array}{l}\text { Department of } \\
\text { Operation }\end{array}$ & Operations & $\begin{array}{l}\text { Crime prevention, public } \\
\text { order, public safety }\end{array}$ \\
\hline 3. & $\begin{array}{l}\text { Department of } \\
\text { Logistics and Supply }\end{array}$ & Logistics and supply & $\begin{array}{l}\text { Works and Public Estate } \\
\text { Management }\end{array}$ \\
\hline 4. & $\begin{array}{l}\text { Department of } \\
\text { Training and } \\
\text { Development }\end{array}$ & Training & Human Resources \\
\hline 5. & $\begin{array}{l}\text { Department of } \\
\text { Research and } \\
\text { Planning }\end{array}$ & $\begin{array}{l}\text { Planning, Research } \\
\text { and Development }\end{array}$ & Statistics and Data \\
\hline 6. & $\begin{array}{l}\text { Department of } \\
\text { Criminal } \\
\text { Investigation }\end{array}$ & $\begin{array}{l}\text { Force Criminal } \\
\text { Investigation Dept } \\
\text { (FORCID) }\end{array}$ & Investigation \\
\hline 7. & $\begin{array}{l}\text { Department of } \\
\text { Information } \\
\text { Technology }\end{array}$ & $\begin{array}{l}\text { Information and } \\
\text { Communication } \\
\text { Technology }\end{array}$ & $\begin{array}{l}\text { Communication } \\
\text { Management }\end{array}$ \\
\hline
\end{tabular}

Wikipedia (2015) 
A Federal Investigation and Intelligence Bureau (FIIB) was to be set up as the successor to the Directorate of Intelligence and Investigation; three directorate were established for operations, administration and logistics, each headed by a deputy inspector general.

The Directorate of Operations was subdivided into four units under a deputy director operation, training, communications, and the mobile police.

The Directorate of Administration was composed of an administration unit headed by an assistant inspector general (AIG), and budget and personnel units under commissioners.

The Directorate of Logistics had for units - procurement, workshop/transport, supply and work/maintenance - under AIGS were authorized to transfer officers up to the rank of chief superintendent, to set up provost units, to deploy mobile units, and to promote officers between the ranks of sergeant and inspector.

The above three Directorates were renamed Departments.

Department of Criminal Investigation

The Department of Criminal Investigation (DCI) is divided into sections, with most of them headed by Commissioners of police (CP). The Sections are:

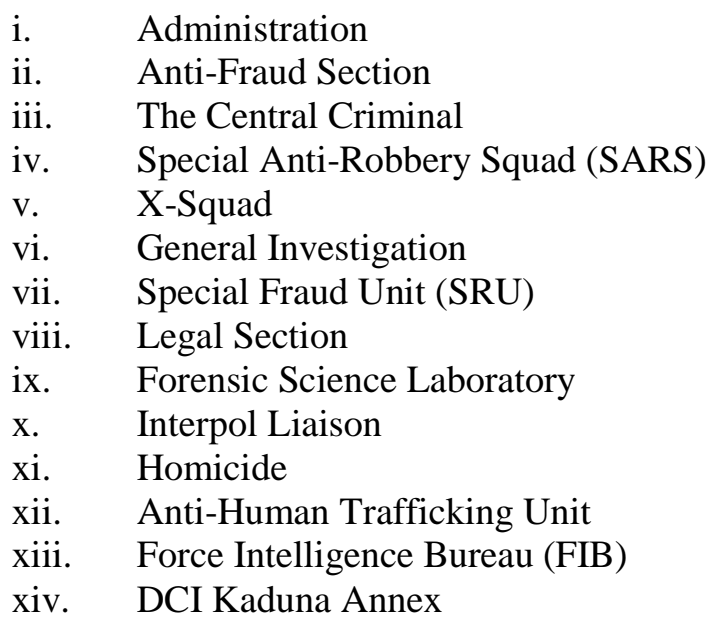

\section{Police Mobile Force}

The Police Mobile Force was established as a strike or Anti-riot unit under the control of the inspector-general of police to counter incidents of civil disturbance. There are presently 12 Mopol commands, 52 police squads which are spread amongst 36 state commands and Federal Capital Territory (FCT) 
AFRREV, 10 (1), S/NO 40, JANUARY, 2016

Supervision of Nigeria Police

Three major Governmental Agencies oversee the control and supervision of the Nigerian police.

- The Police Service Commission

- The Nigeria Police Council

- The Ministry of Police Affairs

Inspector General of the Nigerian Police

\section{Name}

1. IGP Louis Edet

2. IGP Kam Salem

3. IGP Muhammadu Dikko Yesufu

4. IGP Adamu Suleiman

5. IGP Sunday Adewusi

6. IGP Etim Inyang

7. IGP Muhammadu Gambo-Jimeta

8. IGP Aliyu Atta

9. IGP Ibrahim Coomassie

10. IGP Musiliu Smith

11. IGP Mustafa Adebayo Balogun

12. IGP Sunday Ehindero

13. IGP Mike Mbama Okiro

14. IGP Ogbonna Okechuku Onoro

15. IGP Hatif Ringim

16. IGP Mohammed Dikko Abubaka

17. IGP Suleiman Abba

18. IGP Solomon Arase

\section{Period of Office}

$$
\begin{aligned}
& 1964-1966 \\
& 1966-1975 \\
& 1975-1979 \\
& 1979-1981 \\
& 1981-1985 \\
& 1985-1986 \\
& 1986-1990 \\
& 1990-1993 \\
& 1993-1999 \\
& 1999-2002 \\
& 2002-2005 \\
& 2005-2007 \\
& 2007-2009 \\
& 2009-2010 \\
& 2010-2012 \\
& 2012-2014 \\
& 2014-2015 \\
& \text { Inspector General of Police }
\end{aligned}
$$

\section{Functions of the Police}

It is problematic to define contemporary police mainly in terms of their supposed role and function (Kurian, 2006). According to Sullivan (2005), the uniting feature of police work is not a particular social function, whether it is crime, control, social service, order maintenance or political repression. Rather, it is that all demands on the police involve something that ought not to be happening and about which someone had better do something now.

The Nigeria Police Force performed conventional police functions and responsible for internal security generally; for supporting the Prison, Immigration and Customs Services and for performing Military duties, within or outside Nigeria as directed. (Nigeria Police Watch, 2011). 
Society through its law gives its government wide powers for the purpose of efficient and effective preservation of law and order, protection of citizens from suffering, fear and loss of life and property produced by crime and violent conflict. The police is inherently, the most visible symbol of any government power and authority and primary enforcement of its law; an institution of social control in the hands of those who are managers of the state. (Obaro, 2014).

\section{The Problems of Nigeria Police}

The integrity of the Nigeria police has been eroded by the ineffectiveness and inefficiency in their constitutional responsibilities to the society. As a nation, our security report has now been worse. Terrorism visited their targets at will; armed robbers hold up towns to ransom for hours as if in stubborn defiance while reports of ritual killings are on the increase, and kidnappings continue unabated. Standing between the wave of crime and the people is the police force that seems to have caught unprepared; a force that is poorly trained, poorly equipped, poorly paid and deeply corrupt. (Nwachukwu, 2012).

The Nigeria Police suffer deficit of public legitimation and support, the public do not trust and support the police because their performance is poor. Also the public regards the character and level of accountability of the police as grossly unsatisfactory. The police in the nation are generally feared but not respected, distracted and despised by the Nigeria public (Ibidapo-obe, 2003).

According to Olong and Agbonika (2013) one sad aspect of the Nigeria Police under the present dispensation is that the police have become a tool for the perpetration of electoral malpractice and an instrument in the hand of the ruling government to frustrate popular democracy.

The Nigeria Police are becoming notorious for right of abuse, corruption and lack efficiency. The Police personnel are poorly paid. They do not get proper training, the politicians treat them like private. (Lukman, 2014)

The Nigeria police under the present dispensation is that the policy have become a tool for the perpetration of electoral malpractice and instrument for victizing political opponents and parties. (Oteh and Alexander 2012).

There is today a widespread feeling of fear and insecurity in the land. Nigerians do not feel safe anywhere; at home, at work, on the highways, at the airports and even within the hallowed precints of places of worship. It is possible to link the unprecedented rise in violent crimes and the alarming new dimensions of organized terrorist activities to the refusal of the authorities to engage in meaningful dialogue with significant segments of civilian population. Some Nigerians see this development as the only available option to express deep-seated frustration and anger, for violence invariably begets even further violence. 
According to Okeineme (2010) another area where the force seems to have performed below expectation in the past and needs to improve upon is the area of violence control and management. Some Nigerians especially the youths have been felled by police bullets in the name of controlling crowd violents. In such cases, many of such culprits attribute such unfortunate occurrence to accidental discharges.

\section{The Impediments to Effective Policing in Nigeria}

Nigeria police performance is unsatisfactory; the police are ineffective and inefficient in their job of crime prevention, criminal investigation, and response to distress calls by citizens. The poor performance is due to several factors, but mainly to lack of development of productive and social infrastructure in society; inappropriate policing strategies; inadequate intelligence gathering, analysis and utilization skills and facilities, inadequacy of officers in terms of quality and training at various ranks; poor training and conditions of service; lack of public co-operation; grossly inadequate logistics (especially transpiration; telecommunication, arms and ammunition etc); poor remuneration and lack of motivation by the force and superior officers. The challenge is that an ineffective police force cannot command the respect of the public. (Adeyemi, 2001) Ididapa-Obe,

\section{Dearth of Manpower}

One of the glaring problems of the Nigeria police force is lack of manpower. The force is the principal law enforcement agency in Nigeria with a staff strength of about 371,800 consisting of 36 commands grouped in 12 zones and 7 administrative organs. (Wikipedia, 2015). This manpower strength is definitely too minimal to cope with the policing of the population of Nigeria which is estimated to about 150 million.

\section{Corrupt Practices}

Policing in Nigeria cannot be discussed without using corruption as a conceptual framework of study. Corruption is a problem since the practice is increasing and not reducing in the police force. Policing in the country has been characterized by a culture of corruption and lack of accountability. Police men engage in the various forms of extortion of money from the public i.e. money is demanded from suspect to secure bail at the police stations.

\section{Insufficient Funding by the Government}

Many Nigerians don't know that the only thing the Nigeria Police officers don't buy for themselves is perhaps their guns and bullets. Most times they have to commandeer a commercial bus to convey them to their destination. Most times even the guns are fastened around their shoulders with whatever ropes they can hands upon. In most cases these officers buy the cloth materials for their uniforms and sew them with their personal money, buy their shoes, buy recharge cards to make calls on cases, 
buy petrol for their vehicles, buy torches and candles to use in their offices, buy biros and writing materials they need for their work. As if that is not enough, if they are lucky to be provided with living quarters in barracks, the environment is so deplorable that only pigs can live in such places without being demoralized or even contacting diseases. They have no meaningful insurance cover that will make them rest assured that their family will not suffer in case they die in service. When a colleague is killed in service, his living colleagues are the ones who contribute money to bury their dead colleague and support his family (Onwuka, 2011).

\section{Lack of Public Confidence}

A lot of people are seeing the police as an enemy and as such cannot report crime to them. Policing in any nation is by the consent of the people and the police must win back their consent.

People are scared to giving information of hoodlums, kidnappers, armed robbers within their street to the police for the fear of being sold out. There are series of cases in which the information given to the police later traced to the informants. And apart from the released of the culprits who walk feely in the street, the police sources of information are also released to them.

\section{$>$ Lack of effective Community Policing}

According to Oyegoke (2003), a well-integrated community based policing could be a veritable source of security information to the police and other ancillary security agencies, to counter various acts of criminality. The grass roots people have distrust for Nigeria police and as such giving vital information becomes an onerous task.

\section{Strategies for Effective Policing in Nigeria}

In order to have effective policing in Nigeria several strategies need to be put in place by the government. The following are some important strategies toward effective policing in Nigeria.

\section{Re-orientation of the Police}

To improve the image of the police and enhance the public cordial relation, symposia, seminars and workshops should be organized by the police authority to change the minds of its personnel on corruption as to enhance their integrity.

\section{Manpower Training}

According to Arase and Iwuofor (2007) training is an invaluable tool for the effective policing of any society. An untrained or ill-trained police officer lacks the requisite knowledge, skill and attitude for effective crime control and is also a threat to the society. Regular training programmes should be organized to enhance 
professionalism and productivity of the Nigeria police in the critical areas of investigation, guard duties, surveillance/intelligence gathering, conflict resolution and management, prevention of cases etc.

\section{$>$ Infrastructural development}

First and foremost, the government should embark on the reconstruction of barracks and the renovation of the existence as the accommodation of more officers and men at the barracks will enable speed response to distress call from citizens. Functional vehicle, patrol motorcycle and helicopters will enhance a wider aerial surveillance and patrol activities, patrol boats for the water ways security, should be provided by the Government. Also the introduction of closed circuit television (CCTV) in every nook and cranny in the country.

\section{$>\quad$ Provision of Firearms}

The Government should purchase modern firearms and ammunition to replace those obsolete arm being paraded daily by the Nigeria police force. The provision of more bullet proof vests, helmets will help the force to withstand any case of insecurity at anytime in the country.

\section{Motivation}

Police professions is known to be an enduring one but this could not be considered as the total absence of motivation and incentives to members of Nigeria Police Force. Therefore, police men should be highly motivated for higher performance. The following are considered important incentives for the police.

1. Salary payments should be regular.

2. Police insurance programmes should be revitalized and be expanded to cater for the family of those who died in active service.

3. Police pension scheme should be made pensionable.

4. Police Uniform (Dressing Kit): Police uniforms, boot, shoes and other kits should be supplied by the Government.

\section{Public Responsibility}

It is of old that policing is exclusively left in the hand of law enforcement agent alone. In this modern era, effective policing is collective responsibility of all member of the public. The government, the governed and the police personnel themselves are duty band to have a stake in the country policing system.

Agreed that God is the ultimate security provider, nevertheless, it is suicidal to live a careless life. Therefore, it is advisable to be mindful of the activities of criminals in one's place of work, place of worship, home, while travelling and anywhere are may find oneself. Give useful and timely security information to the police for prompt 
attention. Information is an engine to the vehicle of security management. Criminals are not spirit; they are human beings, so expose them. Police officers are neither magicians nor miracle workers. Therefore, they need information to work with.

\section{The Organization of an Ideal Community Based Policing}

Grassroots people and lovely individuals such as villagers, drivers, messengers, farmer, prostitutes etc. could prove useful in gathering vital security information, especially if such individuals enjoy police confidence and support. In order to ensure the success of a community base policing, the following should be taken into consideration:

1. The people should be encouraged to cultivate the habit of passing security information to the police without delay.

2. Members of the group should voluntarily subscribe to the rules and regulations put in place in the community.

3. The group should have strange sense of patriotism.

4. The group should have genuine desire to assist the Security agencies, especially the police.

Community based policing in a security system where people living in one place or district are sensitized, encouraged and empowered to appreciate and take part in the joint effort for the protection of lives and property in their domain. The system of community based policing is more desirable in less developed countries where the instrument of conventional security management are lacking or inadequate. Conventional security arrangements alone cannot guarantee the desired security where community based policing is relegated to the background.

\section{The Role of Traditional Rulers}

Traditional rulers at all levels wield enormous influence over their subjects. They possess authorities that, if judiciously used, could help in no small measure to guarantee security of lives and properties in their domains. They occupy the position of middlemen between their subjects and the police.

The traditional ruler can be of help to the police in the following ways.

(a) Attending or sending representatives to the Police Community Relations Forum.

(b) Organizing vigilant and other community services in their areas.

(c) Enlighten their subjects on security matter.

(d) Passing relevant security information to the police.

(e) Identification of criminals in their communities.

(f) Mobilizing their subjects to support the police financially, materially and in other areas they may deem fit. 
AFRREV, 10 (1), S/NO 40, JANUARY, 2016

\section{Conclusion}

Considering the factors that hinder the efficiency and effectiveness of the Nigeria Police, expecting miracle in their performance amount to unrealistic imagination. Security cannot be compromised, it is the life wire of any nation and is ranked the highest amongst the basic needs of human beings. Effective policing gives the people the confidence and vigour to pursue their legitimate activities. It is the greatest legacy any government has for the people. The Nigeria police should be repositioned to measure up with the modern day policing by retraining towards attitudinal change, professional efficiency and effectiveness among the officers and rank and files. There is a great need for cordial relationship between the police and the public. The government should encourage the Nigeria Police by proper funding and welfare activities.

\section{References}

Adeyemi, A. A. (2001). "Corruption in the Administration of Justice." Paper at the National Conference on the Problem of Corruption in Nigeria, organized by Nigerian Institute of Advanced Legal Studies, Lagos and held at the Chelsea Hotel, Abuja, March 26 - 29

Alemika E. E.O. and Chukuma, I. (2000). Police community violence in Lagos, Lagos: Center for law enforcement education. In Arase, E.S., Iheanyi P.O.I (Eds.) (2007). Policing Nigeria in the 21st Century. Ibadan Spectrum Books Limited. $\mathrm{P}$ xxiv

Ibidapo-obe, (2003). Forward. In Jike, V.T. (Ed.). The Nigeria police and the crisis of law and order, A Book of Readings, Lagos: NISS Publications, p 111

Kurian, T.G. (2006). Police - Encyclopedia. World Encyclopedia of Police Forces and Correctional Systems. Detroit Mich: Thomason Gale.

Lukeman, A.O. (2014). Why Nigeria police remains a failure in our democratic setting. Leadership: ng/opinions/Nigeria pshc-democratic setting. Accessed November 2014

Nigeria Police Watch (2011). Policing your police. http://www.alnigerianhistory.blogspot.com. Accessed 10/10/2014.

Nwachukwu, E. (2012). "Security Challenges and the reform of Nigeria Police". File. $11 \mathrm{H}$ : the police 7 . Ltn

Obaro, A.O. (2014). The Nigeria police force and the crises of legitimacy: Re-defining the structure and function of the Nigeria police. European Scientific Journal, March 2014 edition Vol. 10 No 8. ISSN 1857-7881 (print) e-ISSN 1857 7431

Copyright (C) IAARR, 2007-2016: www.afrrevjo.net

Indexed African Journals Online: www.ajo.info 
AFRREV, 10 (1), S/NO 40, JANUARY, $2016 \mid 72$

Okeieneme, G. (2010). - "Challenges of effective policing in Nigeria." Retrieved 31/11/2015 www.nigerianbestforum.com/.../challenge

Olong, M.A. \& Agbonika, J. A.C. (2013). Re-awakening the state police controversy in Nigeria: Need for rethinking. International Journal of Asia Social Science. $3(I I): 2307-2314$

Onwuka, A. (2011). Why Nigeria Police is Corrupt and Ineffective. Nigeria Police Watch. August 9, Htt://Nigeria.profilewatch

Oteh, C.O. \& Mexander F.N. (2012). The Nigeria politics, safety and public policing: An Overview. International Journal of Asian Social Science. 2(7):79

Oyegoke, O. A. (2003). Private security management in Nigeria. Benin: Petersam Books (Publisher) p. 25.

Sullivan, L.E. (2005). Encyclopedia of Law Enforcement. Thousand Oaks: Saga Publications, New York (cited in Obaro)

Tamuno, T.N. (1970). The police in modern Nigeria. Ibadan: University Press p.164.

Umeagbalasi, E. \& Ijeoma, J. (2013). Nigeria police force: The good versus the bad \& ugly. Nigeria Master Web Citizen info@intersocietyng.orgumeagbalasi@yahoo.com accessed 11/12/2014

Wikipedia (2015). "Nigeria Police Force": Intepol. http://Icwebz.ioc.gov/frd/cs/profiles/Nigeria 